\title{
시민사회가 바라본 2018 한국의 OECD DAC 동료검토
}

목 차

\section{I. 들어가며}

II. 2018 OECD DAC 동료검토와 한국 시민사회

1. 동료검토 사전 준비 과정과 시민사회의 참여

2. 시민사회의 대응과 개입

III. 시민사회가 바라보는 2018 동료검토 결과와 핵심 개선 과제

1. 지속가능발전을 위한 한국의 노력 강화

2. 개발 효과성 제고 노력 강화

3. ODA 목표 달성을 위한 현실적인 로드맵 마련 및 시민사회 협력 확대

4. 한국의 ODA 추진 체계 지속 개선

5. 시민사회에 대한 인식 개선 및 협력 강화

6. 투명하고 책임 있는 소통과 정보 제공 확대

7. 인도적 지원 전략 개선

IV. 맺으며

참고 문헌 


\section{요 약}

본 원고는 한국이 2010년 경제협력개발기구(Organisation for Economic Cooperation and Development, OECD) 개발원조위원회(Development Assistance Committee, $\mathrm{DAC}$ )에 가입한 이후, 두 번째로 받은 “동료검토(Peer Review) 보고서”를 시민사회 관점에서 분석하고, 동료검토 권고 사항인 시민사회와의 파트너십을 강화하는 방법을 모색한 시론적 성격의 글이다.

동료검토는 $\mathrm{OECD} \mathrm{DAC} \mathrm{회원국이} \mathrm{국제개발협력에} \mathrm{있어서} \mathrm{갖춰야} \mathrm{할} \mathrm{최소한의} \mathrm{기준}$ 과 요건 제시 및 상호 학습을 위한 목적으로, 권고 사항 이행에 대한 강제성은 없다. 그럼에도 불구하고 국제 기준에 비추어 한국의 국제개발협력 정책의 현주소를 점검하고 개선해 나가는 이정표와 가이드라인이 된다는 점에서 정책 제언의 근거적 의미가 크다. 주변의 많은 우려 속에 한국이 OECD DAC 가입을 준비하며 2008년 3월, 처음으로 특별 검토를 받은 이후 어느덧 10년의 시간이 흘렀다. 이번 동료검토 보고서를 통해서도 알 수 있듯이, 그 사이 한국의 국제개발협력도 변화·발전해 왔다. 그런데 이번 DAC 권고 사항에서 시민사회에 대한 인식 개선 및 협력 강화가 빠지지 않는 것을 보면, $\mathrm{DAC}$ 회원국 기준의 진정한 정부·시민사회 파트너십을 형성하고 협력하는 것은 아직도 한국의 도전 과제로 남아 있다는 것을 알 수 있다.

본 원고는 제2장에서 시민사회가 2017년 동료검토 과정에 적극적으로 개입하기 위해 어떠한 대응 노력과 활동을 했는지 설명하였다. 이어 제 3 장에서 2018 동료검토 권고 사항을 시민사회 관점에서 재조명하고, $\mathrm{DAC}$ 가 제시한 권고 사항을 개선하기 위해 시민 사회와 긴밀한 협력을 토대로 한 이행 계획의 마련 및 정책과 제도를 제안하였다. 


\section{I. 들어가며}

한국은 경제협력개발기구(Organisation for Economic Cooperation and Development, 이하 $\mathrm{OECD}$ ) 개발원조위원회(Development Assistance Committee, 이하 DAC) 가입을 위해 2008년 3월 특별 동료검토를 받은 바 있으며, DAC에 가입한 이후 2012년에 첫 번째 동료검토를 받고 5년 후인 2017년 두 번째 동료검토를 받았다. OECD DAC 동료검토 결과와 권고 사항은 이행을 강제하는 구속력은 없지만, 한국 국제개발협력 정책이 국제 기준에 부합하 도록 개선하는 데 기여하는 이정표와 가이드라인이 된다는 점에서 정책 제언의 근거로써 그 의미가 크다. 이에 한국 시민사회 역시 정부의 동료검토 대응 과정을 지켜보면서 이면보고서 (shadow report)인 시민사회 보고서를 내고, 정부 및 방한한 동료검토 실사단과 면담을 진행하 면서 적극적으로 개입하기 위해 노력했다.

이번 동료검토는 2012년 첫 번째 동료검토 이후 한국 정부가 부단히 노력한 구체적인 성과와 개선 사항을 국제사회와 공유하고, 지속적으로 노력하며 개선해야 할 도전 과제를 확인하는 기회였다.

$\mathrm{DAC}$ 는 한국이 2012년 동료검토를 통해 도출된 권고 사항을 대부분 이행했다고 평가(24개 의 권고 사항 중 21 개 이행 완료 및 부분 이행)했으며, 혁신적인 세계시민교육 운영, 국제원조투 명성기구(International Aid Transparency Initiative, 이하 IATI) 가입 등 지난 검토 이후의 발전 사항을 긍정적으로 평가했다. 반면, 한국 공적개발원조(Official Development Assistance, 이하 ODA) 체계 지속 개선, 성평등·환경 등 크로스커팅(cross cutting) 이슈의 주류화, 시민사 회와의 협력 강화 등은 개선해야 할 도전 과제로 지적하고 있다(OECD, 2018).

한국은 2011년, 시민사회를 비롯한 다양한 이해관계자를 개발원조의 파트너로 천명했다. 또한 글로벌 파트너십을 통해 개발원조 패러다임을 원조 효과성에서 개발 효과성으로 재정립한 부산 세계개발원조총회의 주최국으로서 시민사회를 포함한 다양한 파트너들과 효과적인 개발협력 을 위한 부산 글로벌파트너십(Global Partnership for Effective Development Cooperation, $\mathrm{GPEDC})$ 을 모범적으로 이행할 책무를 지니고 있다.

이에 본 원고에서는 동료검토 과정에서 시민사회가 참여하며 관찰한 것을 중심으로 동료검토 결과에 대한 시민사회의 의견을 제시하고자 한다. 특히, 2012년 동료검토 이후 제자리걸음을 하고 있는 시민사회와의 협력 부분에 있어서 시민사회의 의견을 전하고자 한다. 그러나 아직 동료검토 결과에 대한 시민사회의 공동 평가나 논의가 이루어지지 않았으므로, 본 원고에서 전하는 내용이 시민사회의 공식적인 의견이라고 보기는 어렵다. 


\section{2018 OECD DAC 동료검토와 한국 시민사회}

\section{1. 동료검토 사전 준비 과정과 시민사회의 참여}

한국 정부는 2018 동료검토 준비를 위해 2017년 초 국무조정실을 중심으로 관계 부처 및 기관 특별팀을 구성하고, $\mathrm{OECD}$ 안내서에 따라 2012년 동료검토 권고 사항에 대한 한국 정부의 대응과 성과, 현황 등을 기술한 메모랜덤을 DAC에 제출했다(2017년 5월). 이후 DAC 실사단 의 한국 방문 실사 및 캄보디아 현장 실사(2017년 6월)를 거쳐 평가회의와 보고서 작성, 파리 $\mathrm{OECD}$ 회의장에서 개최된 우리나라에 대한 $\mathrm{DAC}$ 동료검토회의(2017년 12월)를 실시한 이후 2018년 2월, 한국에 대한 두 번째 동료검토 보고서가 발표되었다.

동료검토에 두 번째 참여하는 한국의 시민사회 역시 2017년 1월, 국제개발협력민간협의회 (Korea NGO Council for Overseas Development Cooperation, 이하 KCOC) 회원 단체를 중심으로 2017 동료검토 대응 특별팀(task force)을 모집·구성했다. 그리고 동료검토 시민사회 대응팀을 중심으로, 2017년 2월에 한국의 시민사회협력정책 모니터링 및 관련 문서 스터디를 시작하여 $\mathrm{OECD} \mathrm{DAC} \mathrm{동료검토} \mathrm{관련} \mathrm{주요} \mathrm{문서} \mathrm{강독} \mathrm{세미나를} \mathrm{개최하였다.} \mathrm{이어} \mathrm{DAC}$ 공여국들 의 시민사회 협력 전략과 정책 문서를 검토함으로써 한국 정부의 $\mathrm{ODA}$ 전반과 시민사회 협력, 인도적 지원에 관한 시민사회 검토 보고서를 작성하여 시민사회 컨설테이션(consultation, 2017 년 3월)을 거쳐 최종 시민사회 보고서를 DAC 수검팀에 제출(2017년 5월)하였다.

$\mathrm{DAC}$ 에 메모랜덤과 시민사회 보고서를 각각 제출한 정부와 시민사회는 각자 제출한 보고서 를 교환·검토한 후 6월 초에 정부-시민사회 간담회를 개최해 정부의 동료검토 준비 현황을 공유하고 또 시민사회와 관련 의견을 교환하는 시간을 보냈다. 정부의 메모랜덤과 시민사회 보고서를 검토한 실사단은 6월 말 한국에 방문하였고, 한국에 머무는 일주일(6.19 23)간 관련 정부 부처·기관 및 시민사회 단체 등과 간담회를 갖고 다양한 주제에 대한 질의응답을 진행하 였다.

첫 번째 동료검토 과정에서 정부가 시민사회와의 협력을 일종의 요식 절차를 밟는 것으로 인식하는 것에 대한 아쉬움(윤지영, 2013)이 있었다면, 두 번째 동료검토 과정에서는 정부가 시민사회와의 협력을 중요한 절차로 인식하고 또 시민사회와의 간담회에 보다 적극적으로 참여 하는 긍정적인 태도 변화를 느낄 수 있었다. 한국 국제개발협력 정책의 현주소에 대해 정부와 시민사회가 느끼는 온도차나 논의 과정에서 정부 측 답변이 다소 한정적이고 형식적이었다는 
점 등에서는 아쉬움이 남았지만, 시민사회와의 협력에 대한 정부의 태도 변화는 동료검토 과정 을 통한 하나의 긍정적인 변화로 인식되었다. 특히, 정부의 메모랜덤을 간담회 전에 제공받아 시민사회 참석자들이 메모랜덤의 내용을 숙지하고 또 질의 내용을 미리 준비할 수 있었던 점이 긍정적으로 평가되었다.

제I장

국제개발협력 및 인도적 지원 활동을 하는 133 개의 회원 단체로 구성된 $\mathrm{KCOC}$ 는 2017 동료검토 시민사회 대응 특별팀과 완성한 “2017 OECD DAC Peer Review 한국 시민사회 보고서”를 2017년 5월, DAC에 제출하였다. 시민사회 보고서(국제개발협력민간협의회, 2017b) 에는 'ODA 전반', '시민사회협력 분야, '인도적 지원 분야’로 나눠 한국의 국제개발협력 현황의 진단과 개선에 대한 제안을 담았다. 이 보고서는 정부의 입장에서 기술한 메모랜덤에 대한 일종의 이면 보고서로서 한국의 개발협력에 대한 시민사회의 시각을 공유하여 이번 동료검토가 보다 균형 있고 실질적인 평가가 될 수 있도록 돕기 위해 작성되었다.

시민사회 보고서의 경우 시민사회 내 동료검토 대응 특별팀을 중심으로 작성되었기 때문에, 시민사회 단체 간 내부 컨설테이션 과정을 거침으로써 보고서에 대한 시민사회 단체의 책무성과 대표성을 담보하고자 노력했다. 2012년 동료검토와 2015년 중간보고 과정에 참여했던 주체들 을 시민사회 보고서 자문위원으로 활용하여 시민사회 보고서의 연속성을 도모하고 내용의 검증 과정을 거쳤다. 또한 시민사회 보고서를 작성하고 제출하는 과정에서 $\mathrm{DAC}$ 수검팀과 소통하며 한국 방문 실사 기간 중에 시민사회와 별도의 간담회를 추진할 것을 지속적으로 요청하기도 했다. 이성훈 $\mathrm{KCOC}$ 정책홍보위원이 작년 4월, $\mathrm{OECD}$ 포럼 참석차 $\mathrm{OECD}$ 를 방문했을 때 수검팀의 카렌 요르겐슨(Karen Jorgensen) 실사단장과 사전 면담을 통해 한국 시민사회의 이면보고서 작성 진행 상황을 알리고, 한국 방문 기간 동안 시민사회와 별도 간담회를 가질 것을 요청했다. 또 5 월 $\mathrm{DAC}$ 에 시민사회 보고서 송부 시에도 별도의 시민사회 간담회 개최 여부를 문의하며 시민사회 간담회 실시에 대해 지속적으로 요구했다.

$\mathrm{DAC}$ 실사단의 방한 일정과 시민사회 간담회 일정(6.20.)이 확정됨에 따라 시민사회의 적극 적인 참여는 보다 활발하게 이루어졌다. 실사단의 방한 기간 동안 한 차례 개최되는 시민사회 간담회에 참여할 시민사회 대표단을 확정하고, 효율적이고 효과적인 의사 전달을 위해 시민사회 에서는 참석자 간 사전 논의를 통해 시민사회 보고서를 챕터별로 나누어 대응할 수 있도록 역할 분담을 하였다. 또한 참석자 간에 챕터별 질의 내용을 사전에 공유함으로써 중복 질의를 막고, 중요한 이슈들이 골고루 논의될 수 있도록 시민사회 의견 전달을 전략적으로 준비했다. 
2012년 동료검토 당시, 시민사회 간담회에는 OECD DAC 사무국 담당자 한 명과 피검국 대표자 한 명만이 시민사회 간담회에 참석하는 조촐한 간담회였으나, 2017년 시민사회 간담회 에서는 방한한 실사단 전원이 참석할 정도로 시민사회 보고서와 의견에 대한 높은 관심을 드러 냈다.1) 실사단과 시민사회의 면담에서는 2012년 동료검토 이후 시민사회가 생각하는 한국의 $\mathrm{ODA}$ 정책 전반의 진척 사항과 개선 과제에 대한 토론이 주를 이루었는데, 특히 실사단은 정부와 시민사회 간의 협력에 있어서 시민사회가 느끼는 실질적인 변화와 의견에 대해 자세히 질의했다. 시민사회에 대한 정부의 재정 지원 방식 및 규모, 소통 메커니즘과 협력 방식에 대해 구체적으로 질의했고, 그중에서도 당시 국제개발협력 프로젝트에 적용되고 있던 국내 기준의 보조금 시스템에 대한 한국 시민사회의 문제 제기에 공감하며 국제개발 현장에 적용되기에는 한계가 많다는 점에서 우려를 표하였다.

한편, 피검국 대표로 참여한 미국과 뉴질랜드에서는 원본 영수증을 제출하지 않은 채 재정보 고서로 갈음하고, 사업에 따라 현장 방문을 통해 점검하는 방식을 적용한다고 설명해 주기도 하였다. 이는 방한 이후 실사단이 시민사회에 보낸 감사 편지에도 '보조금 시스템이 취약국과 최빈국에 대한 혜택을 축소할 수 있어 우려가 된다(Mags Gaynor, 2017)'고 명시함으로써 국제개발협력 프로젝트에 적용되던 정부 보조금 시스템이 2018년 정부 출연금제도로 전환되는 데 일조하기도 했다.

그 밖에 시민사회와 나눈 의견인 한국 $\mathrm{ODA}$ 의 질적 개선 및 인도적 지원 전략 개정, 최빈국에 대한 비구속성 원조 제공에 대한 노력과 모든 이해 당사자 간 의사소통 개선 노력이 필요하다는 내용, 시민사회와의 협력 관계를 명확히 하고 심화할 필요가 있다는 내용이 결과 보고서에 실제로 명시·인용되었다(OECD, 2018). 이는 시민사회 의견에 대한 실사단의 높은 관심과 시민사회의 적극적인 개입이 잘 맞아 떨어졌음을 반증하고 있으며, 이번 동료검토 보고서가 한국 시민사회의 의견을 대변하여 한국 정부의 개발협력 발전 방안을 제시하고 있음을 알 수 있다.

1) $2017 \mathrm{OECD} \mathrm{DAC}$ 동료검토 시민사회 보고서 발간과 DAC 실사단의 한국 시민사회 간담회 개최 관련 내용을 2017년 6월 20일 연합뉴스에서 보도함. (http://www.yonhapnews.co.kr/bulletin/2017/06/20/0200000000AKR2017062 0071200371.HTML?input=1195m)（접속일: 2018.02.18.) 


\section{III. 시민사회가 바라보는 2018 동료검토 결과와 핵심 개선 과제}

지난 2월 7일, 최종 발표된 동료검토 결과에 대한 정부 보도 자료2)를 보면 $\mathrm{OECD} \mathrm{DAC}$ 는

작년 12 월 파리에서 개최된 동료검토 최종 회의를 통해 한국에 대한 동료검토 보고서 내용을

확정했으며, 2012년 첫 번째 동료검토 이후 한국 정부가 추진해 온 개발협력 정책과 집행 전반 에 대한 개선 노력을 긍정적으로 평가한 것은 물론 한국 $\mathrm{ODA}$ 의 개선과 발전을 위한 12 개의 권고 사항을 제시했다. 또한 2012년 동료검토 보고서 권고 사항을 이행하기 위한 한국의 노력과 대국민 공감대를 형성하기 위한 혁신적인 세계시민교육 운영, IATI 가입 등 지난 검토 이후의 발전 상황( 24 개의 권고 사항 중 21 개 이행)을 특히 긍정적으로 평가했다. 반면, 한국 ODA 체계를 지속적으로 개선할 것과, 국민총소득(Gross National Income, 이하 GNI) 대비 ODA 목표(2030년까지 0.3\%까지 확대)를 달성하기 위한 로드맵 마련, 원조 비구속화 노력 지속, 성평등·기후변화·환경 등 크로스커팅 이슈의 주류화, 시민사회와의 협력 강화 등은 여전히 개선 해야 할 도전 과제로 지적했다(OECD, 2018).

한국의 개발협력 정책이 일부 개선된 것은 사실이지만, 아래 <표 $1>$ 과 같이 $\mathrm{DAC}$ 의 상세 평가 의견과 12 개 권고 사항을 자세히 들여다보면 2012년 동료검토 결과와 크게 다르지 않고, 권고 사항이 지속적으로 반복되고 있음을 알 수 있다.

〈표 1〉 OECD DAC의 한국 동료검토 권고 사항

\begin{tabular}{|c|c|c|}
\hline 평가 항목 & 2012년 권고 사항 & 2018년 권고 사항 \\
\hline $\begin{array}{l}\text { 지속가능 발전을 위한 } \\
\text { 한국의 노력 }\end{array}$ & - 해당 사항 없음 & $\begin{array}{l}\text { - 국내외 지속가능 발전 관련 법규와 정책 조정 } \\
\text { - 협력 대상국에 대한 파급효과를 고려하여 } \\
\text { 정책 간의 우선순위 조정 기제 구축 }\end{array}$ \\
\hline $\begin{array}{l}\text { 개발협력 비전과 } \\
\text { 정책 체계 }\end{array}$ & $\begin{array}{l}\text { - 범정부적 친개발협력 정책 수립을 통한 개 } \\
\text { 발 정책 일관성 강화 } \\
\text { - 대외 및 국내 정책이 협력 대상국에 미치는 } \\
\text { 영향에 대해 다양한 이해관계자가 참여하는 } \\
\text { 분석 실시 }\end{array}$ & $\begin{array}{l}\text { - 사업 승인 과정 간소화 } \\
\text { - 현장 분권화를 통한 신속한 대응력 강화 } \\
\text { - 개발 효과성 제고 및 모든 이해 당사자 간의 } \\
\text { 의사소통 개선을 위한 노력 지속 } \\
\text { - 개발협력 체계 전반에 걸쳐 필요한 역량과 } \\
\text { 기술 검토 }\end{array}$ \\
\hline 개발 재원 & $\begin{array}{l}\text { - 2015년까지 ODA·GNI 0.25\% 원조 규모 } \\
\text { 지속적 확대 이행 } \\
\text { - 양자·다자 원조 및 무상 · 유상 원조 지원 } \\
\text { 시 신중한 접근 } \\
\text { - } 2015 \text { 년까지 양자 원조의 } 75 \% \text { 비구속화 } \\
\text { 이행 }\end{array}$ & $\begin{array}{l}\text { - 2030년까지 ODA·GNI 0.3\% 목표 달성을 } \\
\text { 위한 구체적인 일정과 목표 설정 } \\
\text { - 원조 비구속화 노력 지속 } \\
\text { * 주: 2016년 비구속성 원조 비율은 } 57 \% \\
\text { (경제협력개발기구, 2018: } 54 \text { ) } \\
\text { * 주: 한국의 비구속화 목표는 2016년 하향 }\end{array}$ \\
\hline
\end{tabular}

2) 관계 부처(국무조정실, 기획재정부, 외교부) 합동 작성, ' $\mathrm{OECD}$ 가 바라본 대한민국의 $\mathrm{ODA}$ - 우리 $\mathrm{ODA}$ 에 대한 $\mathrm{OECD}$ 개발원조위원회 <동료검토 보고서> 발간' - (2018.2.6. 배포) 


\begin{tabular}{|c|c|c|}
\hline 평가 항목 & 2012년 권고 사항 & 2018년 권고 사항 \\
\hline & $\begin{array}{l}\text { - 비구속성 원조에 대한 DAC 권고 사항, 아크 } \\
\text { 라선언, 부산 파트너십 목표 준수 } \\
\text { - 취약국 및 고채무빈국에 대한 유상 원조 지 } \\
\text { 원 시 신중한 접근 필요, 유상 원조 확대 } \\
\text { 시 대상국의 경제 상황 및 부채 상환 능력에 } \\
\text { 대한 주의 요구 }\end{array}$ & $\begin{array}{l}\text { 조정됨 (정부, 2018: 120) } \\
\text { - 원조를 가장 필요로 하는 국가에 지원 집중 } \\
\text { 노력 필요 } \\
\text { - 협력 대상국의 여건에 맞는 최적의 자금조 } \\
\text { 달 수단 활용 }\end{array}$ \\
\hline 한국의 개발협력 구조와 & $\begin{array}{l}\text { - 국제개발협력위원회의 정책 결정 및 조정 } \\
\text { 권한 전적 사용 보장 }\end{array}$ & $\begin{array}{l}\text { - 국제개발협력위원회의 의사결정 권한 보장 } \\
\text { 을 통한 한국 } \mathrm{ODA} \text { 체계의 지속 개선 }\end{array}$ \\
\hline $\begin{array}{l}\text { 한국의 원조 지원 수단과 } \\
\text { 파트너십 }\end{array}$ & $\begin{array}{l}\text { - 국가별 협력 전략에 원조 효과성 원칙과 국 } \\
\text { 제사회의 목표 반영 } \\
\text { - 프로그램형 원조 (Programme-Based } \\
\text { Approaches, PBAs) 확대 } \\
\text { - 수원국 국가 시스템 사용 확대 } \\
\text { - 중기 예측성 확대 } \\
\text { - 대학 - 시민사회 단체(Civil Society Organ- } \\
\text { ations, CSOs) - 싱크탱크의 분석 정보 등 } \\
\text { 을 수렴 - 활용 }\end{array}$ & $\begin{array}{l}\text { - 협력 대상국 정부와의 정책 대화 심화 및 } \\
\text { 타 공여 기관과의 전략적 정책 대화 확대 } \\
\text { - 시민사회의 다양한 역할을 인정하는 규범적 } \\
\text { 틀 마련 및 시민사회와의 협력 심화 }\end{array}$ \\
\hline 성과 관리 · 평가 및 교훈 & $\begin{array}{l}\text { - 국제개발협력 평가소위원회의 독립성 강화 } \\
\text { - 사업 수행에 대한 전반적인 모니터링 및 사 } \\
\text { 후 평가 강화 } \\
\text { - 평가 결과 환류를 위한 시스템 구축 } \\
\text { - 이해관계자들(국회, 시민사회, 기업, 연구 } \\
\text { 기관 듣)에게 개발협력 정책 - 전략- 집행 } \\
\text { 절차 및 예산·사업 수행 전반에 대한 폭넓 } \\
\text { 은 정보 제공 확대, 투명성과 책무성 제고 }\end{array}$ & $\begin{array}{l}\text { - 평가소위원회는 위험 분석 및 학습 필요성 } \\
\text { 에 기반을 둔 평가 대상 선정 } \\
\text { - 평가 결과 및 내부 학습 과정의 교훈을 모든 } \\
\text { 이해 당사자와 공유 } \\
\text { - 단위 사업별 예산 규모 및 개발 성과에 대한 } \\
\text { 정보 접근성 개선 }\end{array}$ \\
\hline 인도적 지원 & $\begin{array}{l}\text { - 인도적 지원을 위한 명확한 비전 수립 } \\
\text { - 국제사회의 인도적 지원 원칙 준수 } \\
\text { - 인도적 지원을 위한 신정책 수립 } \\
\text { - 인도적 지원 대상, 지원 내용, 예산 출처의 } \\
\text { 명확화 } \\
\text {-체계적인 성과 학습 및 보고 실시 }\end{array}$ & $\begin{array}{l}\text { - 인도적 지원 전략 개정 및 관련 법률의 적용 } \\
\text { 범위 검토 } \\
\text { - 취약성을 다루는 관련 정책 그룹들 내에서 } \\
\text { 의 활동 강화 }\end{array}$ \\
\hline
\end{tabular}

출처: 윤지영 (2013), 경제개발협력기구 (2014), 경제개발협력기구 (2018) 내용을 저자가 재구성

본 장에서는 이번 동료검토 결과 권고 사항을 중심으로 시민사회 관점에서 한국 국제개발협 력의 주요 개선 과제를 짚어 보고 또 시민사회의 의견을 기술하고자 한다.

\section{1. 지속가능발전을 위한 한국의 노력 강화}

한국은 이번 동표 평가를 통해 개발협력에 대한 인식 증진 노력(상대적으로 많은 예산 배정 등) 및 혁신적인 세계시민교육에 있어서 선도적이라는 평가를 받았다. 그러나 정부가 매년 실시하고 있는 ODA에 대한 대국민 인식조사 결과에 따르면, 대외 원조 제공에 대한 대국민 
인지율은 2012년 이후 지속적으로 감소 추세에 있다(월드리서치, 2016: 11). 특히 2030 개발의 제와 지속가능발전목표(Sustainable Development Goals, 이하 SDGs)에 대한 정부의 관심 및 대중의 인식이 매우 저조한 상황이다. 한국은 지속가능발전을 위한 국제적 노력과 "2030 개발의제'를 포함한 국제공약이 한국의 개발협력 정책과 보다 효과적으로 연계될 수 있도록 정부의 관심 증대 및 시민사회와의 협력 강화를 통한 지속적인 대중 인식 제고 노력을 꾸준히 해 나가야 할 것이다.

한편, 현재 SDGs 이행에 있어 관련법(녹색성장기본법, 국제개발협력기본법, 지속가능발전 법)이 혼재하고 있다. 따라서 관련 법제의 국내 통합 노력과 담당 부처 조정을 통해 지속가능발 전 목표의 자발적 조기 이행국으로서 이행 체계를 구축하고, 형식적인 이행 계획이 아닌 실질적 인 이행 전략을 마련할 필요가 있다.

\section{2. 개발 효과성 제고 노력 강화}

이번 동료검토 보고서에 따르면 한국의 원조는 여전히 사회 및 경제 인프라 분야의 지원에 중점을 두고 있으며, 성평등·기후변화·환경 등 범 분야(cross-cutting)의 이슈에 대한 지침은 마련되어 있으나 실제적인 적용 내용은 분명하지 않은 것으로 나타났다. 이에 범 분야 이슈 관련 체크리스트 사용만 의무화할 것이 아니라, 보다 실질적이고 체계적으로 관련 이슈들이 검토되고 또 프로젝트와 조화를 이룰 수 있는 유인 마련이 시급하다는 지적이다.

2012년 권고 사항 중 ‘원조를 넘어선(beyond aid) 개발’을 위해 대외 및 국내 정책이 협력 대상국에 미치는 영향에 대해 '한국은 의사 결정 과정에서 다양한 이해관계자의 의견을 수렴.활 용하여 개발을 위한 정책 일관성을 강화할 필요가 있다는 내용이 있다. 이를 통해 궁극적으로 범정부적 개발협력 정책 수립을 통한 개발정책 일관성을 강화해야 한다는 것이다. 그러나 2018 동료검토 결과를 보면, 한국의 개발협력 파트너들은 한국의 국제개발협력 정책이 의사 결정으로 이어지는 과정이 항상 명확하지는 않다고 생각하고 있으며(경제협력개발기구, 2018), 특히 민간 부문과 학계 및 시민사회와의 협력 관계에 대한 지침이 거의 마련되지 않은 것으로 확인됐다.

이는 한국에서 강력한 의지를 표명하고 있는 다자 협력에서도 동일하게 나타나고 있다. 한국 은 새로운 다자 협력 전략을 2016년에 확정하고 또 다른 공여국과의 공동 협력 및 광범위한 프로그램 참여에 대한 의지는 있지만, 다른 공여국들과 관련 논의에 적극 참여하고 있지 않는 것이 문제점으로 지적되고 있다. 따라서 한국 정부는 시민사회를 포함한 국내의 다양한 이해관 계자뿐 아니라 타 공여국과의 협력 강화를 통해 정책의 일관성 강화 및 개발 효과성 제고를 
위한 노력을 지속해야 할 것이다.

\section{ODA 목표 달성을 위한 현실적인 로드맵 마련 및 시민사회 협력 확대}

보고서는 한국의 ODA 확대 목표를 현실적으로 재조정했지만(2015년 $0.25 \%$ 배정 $\rightarrow 2020$ 년까지 $0.20 \%$ 배정), 이를 달성하기 위한 구체적인 로드맵이 여전히 마련되지 않은 점을 지적했 다. 또한 2016년 ODA 규모(GNI 대비 0.16\%)가 22억 5천 달러(순지출)인데, 2020년까지 $\mathrm{GNI}$ 대비 $0.2 \%$ 달성을 위해서는 $\mathrm{ODA}$ 규모가 32 억 달러에 달할 것이라 예측하며, ODA 규모를 확대하면서도 $\mathrm{ODA}$ 효과성과 질을 유지하는 것을 한국의 도전 과제로 보았다(경제협력 개발기구, 2018: 53).

$\mathrm{ODA}$ 규모의 꾸준한 확대에도 불구하고, 한국의 시민사회를 통한 개발협력 지원 비율은 2011년부터 현재까지 전체 ODA 규모의 $2 \%$ 에 정체되어 있다. 정부는 2010년 국제개발협력 선진화 방안을 통해 2015년까지 민관 협력 예산을 900 억 원으로 확대한다고 공표했지만 이를 달성하지 못했다. 또한 한국의 개발협력 및 인도적 지원 시민사회 단체들의 한국 ODA 예산에 서 지원받는 금액의 10 배(2015년 기준 4억 달러)에 달하는 자체 민간 재원으로 활동하고 있다.

정부는 국제사회에 약속한 $\mathrm{ODA}$ 규모 확대를 차질 없이 이행하기 위한 구체적인 로드맵을 마련할 때, 시민사회를 통한 지원을 OECD DAC 평균인 $10 \%$ 대로 끌어올리는 중장기 파트너 십 전략을 함께 마련하여 구체적으로 이행해 나갈 것을 촉구한다. “시민사회와의 협력 관계 증진이 한국에 도움이 될 것”이라는 $\mathrm{OECD} \mathrm{DAC}$ 의 권고에 따라 현장 전문성을 갖춘 시민사회 단체들과의 협력을 확대함으로써 한국은 ODA 규모를 확대하면서도 ODA 효과성과 질을 유지 해야 하는 도전 과제를 극복해야 할 것이다.

\section{4. 한국의 ODA 추진 체계 지속 개선}

이번 동료검토 보고서에서는 한국의 $\mathrm{ODA}$ 예산 확대와 함께 부처별·기관별 참여가 증가하면 서 단독형 사업을 추진하는 경우가 많아 정책 일관성에 취약하고, 범정부 차원에서 정책 조정이 필요하다고 평가했다. 이는 한국 ODA 사업 수행 기관이 2013년 44개에서 2015년 34개로 증가했다는 감사원(2017)의 지적처럼, 2012년도 동료검토를 통해 지적된 원조 분절화가 해결되 지 못하고 보다 심화되었다는 비판적인 평가다.

정부는 메모랜덤(2017)을 통해 현지 ODA 협의체를 통한 ODA 조정 역할을 강조했다. 하지 만 $\mathrm{DAC}$ 가 확인한 결과, 26 개 중점 협력국에서 운영되는 현지 $\mathrm{ODA}$ 협의회의 경우에는 한국 
정부 기관만 참여하는 제한된 형태로 운영되고 있는 실정이다(경제협력개발기구, 2018: 69). $\mathrm{ODA}$ 협의회가 원조 분절화를 해결하는 차원의 기관 간 조정 기능을 위해서는 민간 부문, $\mathrm{ODA}$ 사업 시행 기관 및 시민단체 등 다양한 분야 대표자들이 함께 모여 논의하는 자리가 되어야 할 것이다. 뿐만 아니라 한국은 효과적인 개발협력을 이행하기 위해 사업 이행 단계가 아닌 의사 결정 과정에서 시민사회를 포함한 다양한 이해관계자와의 정책 대화를 추진함으로써 개발을 위한 정책 일관성 강화 및 $\mathrm{ODA}$ 추진 체계 개선을 위한 노력을 지속해야 할 것이다.

\section{5. 시민사회에 대한 인식 개선 및 협력 강화}

국제사회는 SDGs를 달성하기 위해 정부-시민사회 파트너십을 확대하고 있으며, 시민사회 를 통한 원조를 양자-다자 원조와 함께 3대 원조 채널의 하나로 중시하고 있다. 반면, 한국의 시민사회와 협력 부분은 2012 년 권고 사항에서 크게 개선되지 못하고, 5 년이 지난 오늘 유사한 권고를 받았다. $\mathrm{OECD} \mathrm{DAC}$ 에서는 이번 보고서를 통해 한국 정부는 국민들의 강력한 지지를 받는 한국의 시민사회를 독립적 권리를 가진 개발협력 행위자로 존중하고, 시민사회의 차별적인 역할을 인정하는 규범적 체계 마련은 물론 이를 통해 시민사회와의 협력을 구체화하고 심화시켜 야 한다고 권고(경제협력개발기구, 2018: 22)했다.

한국의 시민사회 파트너십이 지난 5년 동안 크게 변하지 않은 이유를 OECD DAC에서는 시민사회에 대한 정부의 인식에서 찾고 있으며, 시민사회를 지역 전문성과 기술 전문성을 가진 독립적이고 차별적인 개발 주체로 인식해야 함을 강조하고 있다. 따라서 정부는 시민사회의 다양한 역할을 인정하는 규범적 틀을 조속히 마련하고 또 사업 수행 단계에서 만나는 협력이 아닌, 정책 수립과 프로그램 기획 단계에서 시작해 이행 및 평가 등 전 과정에 보다 실질적으로 시민사회의 참여를 보장하고 의견을 반영하는 등 시민사회와 진정한 협력 관계를 구축해 나갈 것을 당부한다.

\section{6. 투명하고 책임 있는 소통과 정보 제공 확대}

2012년에는 동료검토 결과 투명성과 책무성을 지속적으로 제고하고, 개발협력에 관한 종합 적인 정보를 일반 국민을 포함한 주요 관계자들이 접근하고 이해하기 쉬운 방식으로 제공해야 한다는 권고가 있었다. 그 후 정부는 2015년 12월, IATI에 가입하고 필수 정보를 공개하는 등 정보 공개를 위한 노력을 지속하고 있다.

그러나 현재 공개된 기초 자료로는 한국의 개발협력 현황을 모니터링하는 데 한계가 있고, 
시민사회의 지적(국제개발협력민간협의회, 2017b)처럼 ODA 사업을 수행하는 부처 간 정보 공개 범위 및 방식이 다르고, 이와 관련하여 공개적으로 의견을 제시할 공식 제도도 없는 실정이 다. 따라서 정보 공개 부처의 확대 및 항목 증대, 정보 공개의 충실도 측면에서 지속적인 개선 노력을 통해 의문을 해소하고 문제를 해결해 나가야 할 것이다.

\section{7. 인도적 지원 전략 개선}

한국 정부에 인도적 지원에 대한 적극적인 참여 의지를 표명하며, 인도적 지원 예산을 증액하 고, 예산의 약 $20 \%$ 를 긴급 재난에 보다 적극적으로 사용하고자 하는 것은 환영할 만한 발전이라 고 본다. 하지만 한국 $\mathrm{NGO}$ 들을 통해 지원되는 '긴급구호 유보금'은 전체 인도적 지원 예산에 비해 현저히 적은 비중을 차지하고 있어, 한국 $\mathrm{NGO}$ 들이 긴급 재난에 신속하게 대응하기 위해 서는 '긴급구호 유보금'의 규모가 확대되어야 할 것이다. 또한 동 유보금은 자금 성격상 긴급한 재난 현장에서 유연하게 운용되기 위한 절차의 간소화가 시급하다. 동료검토 보고서에 '2018년 도부터 인도적 지원 민관 협력 프로그램을 통해 지원받는 $\mathrm{NGO}$ 들에게 간소화된 재정 지원 절차가 도입될 것(경제협력개발기구, 2018: 111)'이라고 기술된 부분은 환영할 만하다. 그러나 이것이 2016년 이래 급격히 강화된 행정 절차를 이전 상태로 되돌리는 것을 의미한다면 운영상 의 발전이라고 보기는 어려울 것이다. $\mathrm{DAC}$ 권고에 따라 한국 $\mathrm{NGO}$ 들과의 보다 긴밀한 파트너 십을 통한 국가의 인도적 지원 역량 강화를 위해서는 그동안 한국 $\mathrm{NGO}$ 들이 제안해 왔던 행정 절차의 간소화, 자금의 기금화 등의 제도가 적극적으로 검토되어야 할 것이다.

마지막으로, $\mathrm{OECD} \mathrm{DAC} \mathrm{검토단이} \mathrm{방문한} \mathrm{캄보디아의} \mathrm{경우에는} \mathrm{캄보디아} \mathrm{정부로부터} \mathrm{캄보}$ 디아 국가 개발 전략과의 일관성 측면에서 우수하다고 평가되었다. 그러나 부정부패를 포함한 캄보디아의 고착화된 거버넌스 문제와 인권 탄압 및 정부의 부당한 감시로 인한 시민사회 축소 등으로 캄보디아 정부가 국제사회로부터 지속적으로 비난받고 있는 상황에서 캄보디아 정부와 의 조건 없는 긴밀한 협력의 타당성 및 협력 방식에 대해서는 심각하게 고민하고 재검토할 필요가 있다. 이는 개발원조를 통해 경제개발뿐 아니라 사회개발, 특히 민주적 거버넌스 구축과 시민사회의 역할을 강조해 온 한국의 개발 경험을 공유하는 차원에서 중요한 이슈는 물론 한국 의 개발원조 정책이 국제 기준에 부합하도록 개선하는 길이기 때문이다. 


\section{IV. 맺으며}

지금까지 살펴본 것처럼 이제 한국의 개발협력은 국제사회에서 요구하는 기본적인 체계와 기준을 어느 정도 갖추었다. 그러나 동료검토 결과를 상세히 들여다보며 2012년도 권고 사항과 비교한 결과, 지난 5 년간 이루어진 외적인 성장에 비해 내부의 실질적인 내용면에서는 여전히 개선할 과제가 많음을 알 수 있다.

이번 동료검토 보고서 발간을 계기로 한국에 방문한 샬럿 고니츠카(Charlotte Petri-ornitzka) $\mathrm{OECD} \mathrm{DAC}$ 의장은 동료검토 결과 보고서를 소개하면서, 한국의 개발협력 정책의 발전과 함께 개발협력 분야에 있어서 한국의 역할 확대를 요청했다. 이를 위해서는 범정부적 차원에서 한국 ODA 정책 및 집행 개선을 위한 노력이 선행되어야 할 것이며, 국제사회와 한국의 시민사 회는 이번 동료검토 결과 보고서가 앞으로 우리 정부의 ODA 정책 및 집행 개선 노력에 박차를 가하는 기회가 될 것으로 기대하고 있다. 또한 2018 동료검토 보고서 발간회의에서 샬럿 고니츠 카 $\mathrm{DAC}$ 의장의 설명대로 동료검토 보고서는 $\mathrm{OECD} \mathrm{DAC}$ 회원국이 갖춰야 할 최소한의 기준이자 요건을 제시하고, 상호 학습을 위한 목적으로 그 내용이 다소 완곡하게 표현되어 있다는 점을 고려할 때 우리는 한국 $\mathrm{ODA}$ 의 현주소와 개선 과제를 보다 엄밀하게 직시하고 성찰하는 태도가 요구된다.

시민사회는 이번 동료검토 보고서가 한국 개발협력 전반에 대한 현황을 점검하고, DAC가 권고한 도전 과제에 있어서 범정부적인 관심과 이행을 촉구하는 주요 장치이자 계기로 인식하고 있다. 이에 한국 정부 또한 동료검토 결과를 한국의 $\mathrm{ODA}$ 를 국제사회와 국민들에게 알리는 홍보 기회로 활용할 뿐 아니라, $\mathrm{OECD} \mathrm{DAC가} \mathrm{제시한} \mathrm{권고} \mathrm{사항에} \mathrm{대한} \mathrm{깊은} \mathrm{성찰을} \mathrm{토대로}$ 충분히 학습하고 또 문제 해결을 위한 이행 계획을 조속히 마련하여 한국의 국제개발협력 정책 과 제도가 도약하는 계기로 삼기를 기대한다.

국제개발협력기본법)은 빈곤 완화와 인도적 지원을 한국 개발협력의 핵심 동기로 제시하고 있다. 한국 시민사회 역시 국제개발협력이 국익을 넘어서 지구촌의 가난한 이웃들과 연대하는 약속이자, 국제사회에서 높아진 한국 정부의 위상과 책무를 실천하는 길임을 강조4)하고 있다. 이러한 위상과 책무에 걸맞게 이번 동료검토 권고 사항을 중심으로 향후 한국의 정책 개선

3) 국제개발협력기본법 (국회, 2010) 제 3조는 "국제개발협력은 개발도상국의 빈곤 감소, 여성·아동·장애인의 인권 향상, 지속 가능한 발전 및 인도주의 실현은 물론 협력 대상국과의 경제협력 관계를 증진하며 국제사회의 평화와 번영을 추구하는 것을 기본 정신으로 한다"고 규정하고 있다.

4) 국제개발협력시민사회포럼, (2013.2.5.); 한국 정부의 국제개발협력 정책을 답보하고 있다. 
과제를 선정하고 이행할 때, 한국의 개발협력이 가시적 성과를 넘어서 내실을 채워 나가는 ‘속이 꽉 찬' 개선과 발전 방안이 제안되고 실행되기를 당부한다. 이를 위해 한국의 시민사회도 함께 노력할 것이다. 


\section{참고 문헌}

관계 부처 합동. 보도 자료 "OECD가 바라본 대한민국의 $\mathrm{ODA}$ - 우리 ODA에 대한 $\mathrm{OECD}$ 개발원조위원회 <동료검토 보고서> 발간.” (배포일: 2018.02.06.) .

국제개발협력시민사회포럼. “[논평] 한국 정부의 국제개발협력정책 답보하고 있다.” 참여

연대 홈페이지 (2013.02.05. 게재). http://www.peoplepower21.org/International/ 993780 (접속일: 2018.02.18).

국제개발협력민간협의회. 2017a. "OECD DAC Peer Review 관련 주요 문서 강독"

국제개발협력세미나 자료집 (2017.02.27. 환경재단 레이첼카슨홀에서 개최). 2017b. 『2017 OECD DAC Peer Review 한국 시민사회 보고

서』. 서울: 국제개발협력민간협의회(KCOC).

윤지영. 2013. “시민사회에서 바라본 2012년 한국의 OECD DAC 동료검토. 『국제개발 협력』2013-1호: 70-82.

월드리서치. 2016. 『2016년도 ODA 국민 인식 조사 결과보고서』. 서울: 월드리서치. 경제협력개발기구(OECD). 2013. 『대한민국 $\mathrm{OECD}$ 개발원조위원회 개발협력 정책·집행

평가 2012 (Korea Development Assistance Committee(DAC) Peer Review 2012)』국무조정실 역. 세종: 국무조정실.

. 2018. 『OECD 개발협력 동료검토: 대한민국 2018 (OECD

Development $\mathrm{Co}^{-}$operation Peer Reviews: Korea 2018)』국무조정실 역. 세종: 국무조정실.

대외경제협력기금(EDCF). 2017. "2017 OECD DAC 동료검토의 이해” ${ }^{\mathrm{EDCF}}$ 이슈 페이퍼』 vol.6(3).

Mags Gaynor. 2017. Civil Society Meeting Seoul Thank You Letter PEER/ $\mathrm{MG}(2017) 01$ (KCOC 내부 문서)

OECD. 2012. "Korea Development Assistance Committee(DAC) Peer Review 2012." Paris: Organisation for Economic Cooperation and Development (OECD).

2018. "OECD Development Co-operation Peer Reviews: Korea.” Paris: Organisation for Economic Cooperation and Development (OECD). 